\title{
Lithium induces mortality in medulloblastoma cell lines
}

\author{
ALICE RONCHI $^{1}$, ROBERTA SALAROLI $^{1}$, STEFANO RIVETTI $^{1}$, ELENA DELLA BELLA ${ }^{1}$, \\ TIZIANO DI TOMASO ${ }^{1}$, MANUELA VOLTATTORNI ${ }^{2}$, SILVIA CAMMELLI $^{1}$, CLAUDIO CECCARELLI $^{1}$, \\ FELICE GIANGASPERO $^{3}$, ENZA BARBIERI ${ }^{1}$ and GIOVANNA CENACCHI ${ }^{1}$
}

\author{
${ }^{1}$ Clinical Department of Radiological and Histopathological Sciences, University of Bologna Alma Mater Studiorum, Via \\ Massarenti 9, 40138 Bologna; ${ }^{2}$ Interdepartmental Center for Biotechnology, University of Bologna Alma Mater Studiorum, \\ Via Beverara 123, 40131 Bologna; ${ }^{3}$ Department of Experimental Medicine, University of Rome La Sapienza, \\ Viale Regina Elena 324, 00161 Rome and Neuromed IRCCS, Via Atinense 18, 86077 Pozzilli, Italy
}

Received March 24, 2010; Accepted May 10, 2010

DOI: 10.3892/ijo_00000724

\begin{abstract}
Lithium is the main therapeutic agent for the treatment of bipolar disorders but nerve cells are not the sole target of this drug. Indeed, lithium has been reported to target numerous cell types and to affect cell proliferation, differentiation and death. Lithium targets a variety of enzymes among which there is GSK-3ß and a number of cell responses elicited by lithium are mediated by the Wnt pathway that is involved in medulloblastoma (MB) pathogenesis. We studied the in vitro effects of lithium on two different MB cell lines: D283MED and DAOY. High doses of lithium inhibited GSK3- $\beta$, decreased cell proliferation and induced nonapoptotic cell death in both cell lines independently by intracellular levels of B-catenin that is consistently high only in D283MED. At clinical doses, the anti-neoplastic effects were observed only in this cell line, highlighting the importance of a specific molecular background in determining the target therapy response. In conclusion, lithium could be a promising drug in $\mathrm{MB}$, but an accurate molecular profile predictive of drug response still needs to be clarified.
\end{abstract}

\section{Introduction}

Lithium is known to target nerve cells and is still being used for the treatment of nervous disorders (1). However, a multiplicity of cell responses is elicited by lithium outside the nervous system and has profound effects on a variety of processes, including metabolism, cell proliferation and development $(2,3)$. In particular, lithium is described as an inhibitor of the cell cycle (4-7) and an accelerator of cell death (8-10). Although some of these data may be debatable,

Correspondence to: Professor Giovanna Cenacchi, Clinical Department of Radiological and Histopathological Sciences, Via Massarenti 9, 40138 Bologna, Italy

E-mail: giovanna.cenacchi@unibo.it

Key words: lithium chloride, medulloblastoma, glycogen synthase kinase- $3 \beta$ the idea is thus raised that lithium may have antitumor properties. These effects are however cell-type dependent: on the one hand, lithium stimulates cell proliferation in mammary tumour cells (11), and on the other, it inhibits cell proliferation in melanoma (12), hepatocellular carcinoma (13) and prostate cancer (7), and it blocks glioma cell migration and invasion in vitro (14). Lithium chloride can also induce apoptosis in several cell types $(8,15)$, even if it has been reported to have anti-apoptotic, especially neuroprotective, effects in certain experimental settings (16-19). Lithium acts by targeting various signalling pathways and cellular enzymes: a central action of lithium is a non-ATP competitive inhibition of glycogen synthase kinase-3ß (GSK-3ß) (20). GSK-3ß belongs to a family of highly conserved serine/threonine kinase and is involved in many biological processes, including cell cycle progression, gene transcription, apoptosis/survival, cellular metabolism, cell movement, tumorigenesis, cytokinesis and embryonic development (20-23). Lithium mimics the effects of Wnt signalling activation by inhibiting the activity of GSK-3ß, which is also involved in the degradation of B-catenin. Activation of the canonical Wnt pathway stabilizes cytosolic B-catenin, which translocates to the nucleus and then stimulates T-cell and lymphoid enhancer factors, leading to upregulation of different target genes (24). Several studies have reported that nuclear $\beta$-catenin is an independent marker of a good outcome in medulloblastoma (MB), an embryonal neuroepithelial tumour of the cerebellum and the most common malignant brain tumour of childhood (25-27). Together, these data suggest that lithium, which is a potent regulator of the Wnt pathway, may interfere with the mechanisms of cell proliferation in MB. Thus, in this study, the effect of lithium was evaluated on two MB cell lines: D283MED, with a p53 wild-type, and DAOY, harbouring a p53 mutation (28).

\section{Materials and methods}

Cell lines, culture conditions and lithium treatment. Human MB cell lines (D283MED and DAOY) were obtained from American Type Culture Collection (ATCC; Manassas, VA). The cell lines were maintained as exponentially growing cultures in Eagle's minimum essential medium (EMEM) with 
Earle's BSS (Invitrogen Corporation; Frederick, MD) supplemented with $20 \%$ heat-inactivated foetal bovine serum (FBS, Invitrogen Corporation), $1 \%$ L-glutamine (Eurobio; Courtaboeuf, France), $0.5 \%$ gentamycin (Euroclone Life Sciences Division; Milan, Italy), $0.5 \%$ neomycin (SigmaAldrich; St. Louis, MO), $1 \%$ non-essential amino acids (Eurobio) and $1 \%$ sodium pyruvate (Eurobio). Cell cultures were maintained at $37^{\circ} \mathrm{C}$ in $5 \% \mathrm{CO}_{2}$. The cells were plated $24 \mathrm{~h}$ before experiments and then $\mathrm{LiCl}$ (Sigma-Aldrich) was added to the culture medium at a dose of $20 \mathrm{mM}$. Cells were analyzed to study early and late responses to the treatment by evaluating: inhibition of GSK-3ß, nuclear $\beta$-catenin expression and $B$-catenin localization, cell proliferation, cell cycle, cell mortality and apoptosis. Moreover, cell mortality was assessed for doses of lithium $<20 \mathrm{mM}$ : 0.5, 1 and $10 \mathrm{mM}$.

Protein expression analysis. D283MED and DAOY cells were harvested 8, 16, 24, 29, 40 and $48 \mathrm{~h}$ after the addition of $\mathrm{LiCl}$ and total protein extracts were prepared as previously described (29), using the following extraction buffer: $1 \%$ Triton, $10 \%$ glycerol, $50 \mathrm{mM}$ Tris $\mathrm{pH} 7.4,150 \mathrm{mM} \mathrm{NaCl}$, $2 \mathrm{mM}$ EDTA pH 8.0, $2 \mathrm{mM} \mathrm{MgCl}_{2}, 50 \mathrm{mM}$ sodium fluoride, $10 \mathrm{mM}$ sodium pyrophosphate, $1 \mathrm{mM}$ sodium orthovanadate and Complete EDTA-free (Roche Diagnostic; Indianapolis, IN) $2 \mathrm{X}$.

Nuclear proteins were extracted 24, 29, 32, 40 and $48 \mathrm{~h}$ after the addition of $\mathrm{LiCl}$, as previously described (29). Aliquots of nuclear pellets were stained with hematoxylineosin (HE) and observed under a light microscope (Carl Zeiss $\mathrm{GmbH}$; Oberkochen, Germany) to verify the lack of cytoplasmic contamination. Western Blotting (WB) was performed as previously described (29), using the following primary antibodies at the respective dilutions in blocking solution: rabbit monoclonal anti-GSK-3ß (27C10, Cell Signaling Technology; Danvers, MA) 1:1000; rabbit polyclonal anti-phospho-GSK-3ß (Ser9, Cell Signaling Technology) 1:1000; goat polyclonal anti-ß-actin (I-19, Santa Cruz Biotechnology; Santa Cruz, CA) 1:1000; rabbit polyclonal anti-ß-catenin (H-102, Santa Cruz Biotechnology) 1:600; goat polyclonal anti-lamin B (C-20, Santa Cruz Biotechnology) 1:1000; mouse monoclonal anti-HSP90 (SPA-830, Stressgen Bioreagents; Ann Arbor, MI) 1:100. Primary antibodies were detected with horseradish peroxidase (HRP)-labelled secondary antibodies at the respective dilutions in blocking solution: anti-rabbit (NA934, GE Healthcare Europe GmbH; Freiburg, Germany) 1:10000; anti-goat (sc-2020, Santa Cruz Biotechnology) 1:1000. Total GSK-3ß, phospho-GSK-3ß and $\beta$-actin were detected on total protein extracts, while $B$-catenin, lamin B and HSP90 detection were performed on nuclear extracts. $\beta$-actin and lamin B were used to check for total and nuclear loading, respectively. HSP90 was used to check for separation of nuclear and cytoplasmic fraction. The experiments were performed in duplicate.

Protein localization analysis. D283MED and DAOY were cultured on glass coverslips and fixed after $24 \mathrm{~h}$ from $\mathrm{LiCl}$ addition with $2 \%$ paraformaldehyde in PBS, for immunofluorescence (IF) staining of B-catenin as previously described (28). IF was performed using a rabbit polyclonal anti- $\beta$-catenin
(H-102, Santa Cruz Biotechnology) as primary antibody at the diluition of 1:100 in blocking solution. Primary antibody was detected with a FITC-conjugated swine anti-rabbit antibody (F0205, Dako Cytomation; Glostrup, Denmark) at the dilution of 1:100 in blocking solution. Nuclei were counterstained with ProLong Gold anti-fade Reagent with DAPI (4',6-diamidino-2-phenylindole) (Invitrogen Corporation). The experiments were performed in duplicate.

Cell proliferation analysis. D283MED and DAOY were seeded in triplicate in 96-well plates at a density of 5000 and 1000 cells/well, respectively, and maintained in $100 \mu 1$ of EMEM 20\% FBS. The cells were analyzed 24, 48, 72, 96 and $120 \mathrm{~h}$ after $\mathrm{LiCl}$ addition and at the corresponding timepoints for untreated cells. Cell proliferation of both treated and untreated cells was assessed using cell proliferation kit I MTT (Roche Diagnostic GmbH), according to the manufacturer's instructions (number 3.2.1). Resulting absorbance was measured using a microplate reader (Sirio-S, SEAC; Firenze, Italy) as the difference between the formazan product absorbance at a wavelength of $550 \mathrm{~nm}$ and the reference absorbance at $660 \mathrm{~nm}$.

Cell cycle analysis. In order to evaluate cell cycle changes induced by the treatment, flow cytometric analysis was performed on D283MED and DAOY as previously described (29). We analyzed specific time points: $24,29,40,48$ and $72 \mathrm{~h}$ after $\mathrm{LiCl}$ addition. The experiments were performed in duplicate.

Cell death analysis. In order to evaluate cell mortality, D283MED and DAOY were seeded in $25-\mathrm{cm}^{2}$ culture flasks and collected 48 and $72 \mathrm{~h}$ after $\mathrm{LiCl}$ addition. Untreated cells were harvested at corresponding time-points. Triplicates of each sample were trypsinized and total cells were suspended 1:1 in Trypan Blue solution (Sigma-Aldrich). Dead and total cells of any sample were counted using a Neubauer chamber. For apoptosis analysis, cells were collected 8, 24, 48 and $72 \mathrm{~h}$ after $\mathrm{LiCl}$ treatment and the percentage of apoptotic cells was measured by flow cytometry, using the Vybrant apoptosis assay kit no. 4 (Molecular Probes, Invitrogen Corporation) according to the manufacturer's instructions. Flow cytometric analyses were performed in triplicate for each sample with a Coulter Epics XL/XL-MCL (Beckman Coulter) equipped with an argon ion laser at $488 \mathrm{~nm}$ wavelength and using the System II software.

Lithium dose assay. D283MED and DAOY were plated in triplicate in 6-well plates at a density of 50,000 cells/well and, $24 \mathrm{~h}$ later, $\mathrm{LiCl}$ was added to the growth medium at 0.5 , 1,10 and $20 \mathrm{mM}$ doses. Total D283MED were collected at $1,2,3,7,10,14,17,21,24,28,31,35,38,42,45,49$ days after the addition of lithium; total DAOY were collected at 1 , 2, 3, 7, 10, 14, 17, 21, 24, 28, 31, 35, 38, 42, 45, 49, 52, 56, $59,63,66,70$ days after $\mathrm{LiCl}$ addition. Untreated cells were harvested at corresponding time-points. Triplicates of each sample were counted using a Neubauer chamber, staining total cells 1:1 in Trypan Blue solution (Sigma-Aldrich). After 49 days for D283MED and after 70 days for DAOY the mortality curves in response to $\mathrm{LiCl}$ were evaluated. 
A.

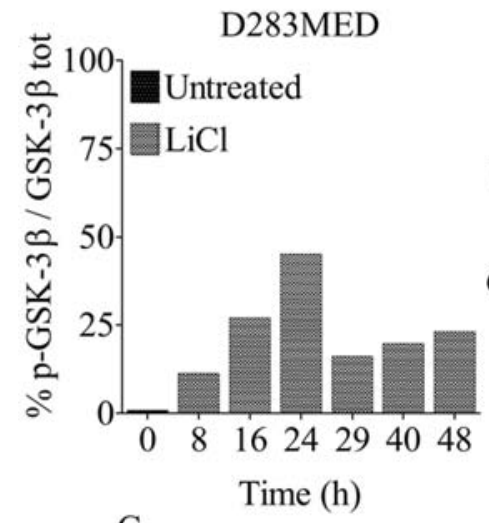

C.

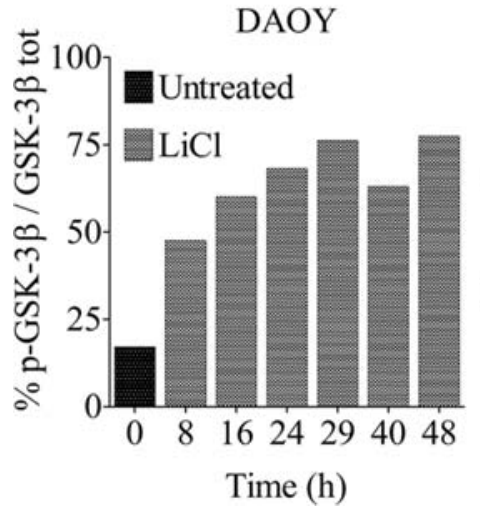

B. D283MED

Time (h)

$0 \quad 81624294048$

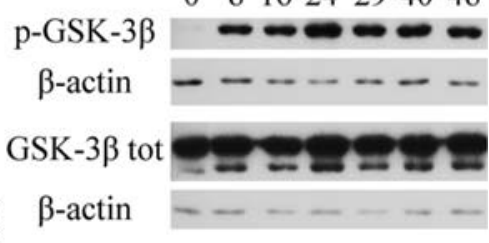

D.

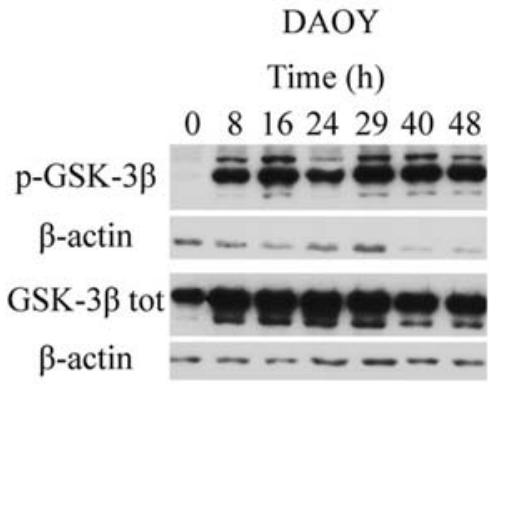

Figure 1. Effect of $\mathrm{LiCl}$ on phosphorylation of GSK-3ß at serine 9 (inactivating) in D283MED (A) and DAOY (C). Whole protein extracts were prepared from untreated cells (dark gray) and from cells harvested 8, 16, 24, 29, 40 and $48 \mathrm{~h}$ after the addition of $20 \mathrm{mM} \mathrm{LiCl}$ (light gray). The expression of phosphoGSK-3ß and total GSK-3ß was examined with WB. The expression of $\beta$-actin served as loading control. Each sample was quantified densitometrically and normalized to the expression of $\beta$-actin. The graphs represent the percentages of phospho-GSK-3B-Ser9 on total GSK-3ß and column bars show the mean of two independent experiments. The images represent one of the two WB, performed on D283MED (B) and DAOY (D) total extracts.

Statistical analysis. Data were analyzed using the Dunnet's test and Bonferroni's multiple comparison test on a graphpad software package for Windows (PRISM5). $\mathrm{p}<0.05$ was considered as statistically significant.

\section{Results}

Lithium inactivates $G S K-3 \beta$ in $M B$ cell lines. WB analysis demonstrated the action of lithium in D283MED and DAOY, inhibiting GSK-3ß function. In particular, the percentage between the phospho-GSK-3ß (inactive) and total GSK-3B share increased after 8, 16, 24, 29, 40, $48 \mathrm{~h}$ from $\mathrm{LiCl}$ treatment compared to untreated cells in both cell lines (Fig. 1A, $\mathrm{B}, \mathrm{C}$ and D). Furthermore, levels of nuclear $B$-catenin were higher than the control in D283MED at 24, 29, 32, 40 and $48 \mathrm{~h}$ after $\mathrm{LiCl}$ addition, with an evident upregulation at 29 and $40 \mathrm{~h}$ from the treatment (Fig. 2A and B). In DAOY, a strong increase in nuclear B-catenin was detectable at $24 \mathrm{~h}$ from lithium treatment and at 29,32, 40 and $48 \mathrm{~h}$ protein levels decreased, until they were lower than the ones of untreated cells (Fig. 2C and D). Each sample was checked for separation of nuclear and cytoplasmic fraction by detection of HSP90 (data not shown). IF investigations showed, in D283MED, a widespread internal staining for B-catenin after $24 \mathrm{~h}$ of lithium treatment and protein levels were higher than the control (Fig. 3A and B). A clear nuclear accumulation of B-catenin could not be affirmed, due to the particular morphology of these cells because they form cellular aggregates and they have a high nucleus/cytoplasm ratio. In DAOY nuclear B-catenin localization was evident $24 \mathrm{~h}$ after $\mathrm{LiCl}$ addition (Fig. 3C and D).

Lithium affects cell proliferation, cell cycle and mortality in $M B$ cell lines. After checking that the metabolic activity was directly proportional to the number of cells, as expected, for the two cell lines of this study (data not shown), cell proliferation MTT assay showed that both D283MED and DAOY had a slower proliferation in response to lithium compared to untreated cells. In particular, in D283MED cell proliferation 48-120 h after treatment was statistically significantly lower than cell proliferation of untreated cells (Fig. 4A). In DAOY, we observed a statistically significant metabolic arrest in response to $\mathrm{LiCl}$, from 48 to $120 \mathrm{~h}$ of treatment, compared to the control (Fig. 4B). Flow cytometry analysis showed a transient decrease in the S-phase of D283MED at $40 \mathrm{~h}$ from $\mathrm{LiCl}$ addition and cell cycle was re-established at $48 \mathrm{~h}$ of treatment (Fig. 5A). In DAOY, a persistent increase in S-phase was observed 24, 29, 40 and $48 \mathrm{~h}$ after $\mathrm{LiCl}$ treatment compared to the control. At $72 \mathrm{~h}$, the number of cells in the G2/M phase increased, while cells in the S-phase 
A.

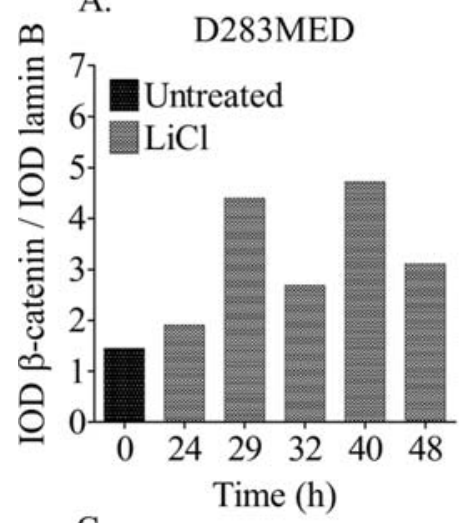

C.

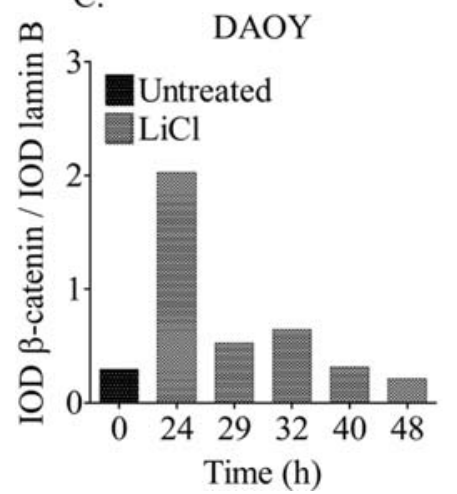

B.

D283MED

Time (h)

$\begin{array}{llllll}0 & 24 & 29 & 32 & 40 & 48\end{array}$

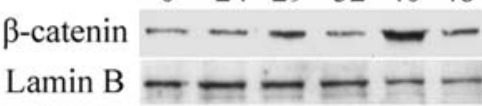

D.

DAOY

Time (h)

$\begin{array}{lllllll} & 0 & 24 & 29 & 32 & 40 & 48 \\ \text { B-catenin } & - & - & \ldots & - & \ldots & \ldots\end{array}$

Figure 2. Effect of $\mathrm{LiCl}$ on nuclear expression of $\beta$-catenin in D283MED (A) and in DAOY (C). Nuclear protein extracts were prepared from untreated cells (dark gray) and from cells harvested 24, 29,32, 40 and $48 \mathrm{~h}$ after the addition of $20 \mathrm{mM} \mathrm{LiCl}$ (light gray). The expression of B-catenin was examined with WB. The expression of lamin B served as nuclear loading control. Each sample was quantified densitometrically and normalized to the expression of lamin B. The graphs represent the relative expression of $\beta$-catenin and column bars show the mean of two independent experiments. The images represent one of the two Western blots, performed on D283MED (B) and DAOY (D) nuclear extracts.

A.

D283MED

Untreated

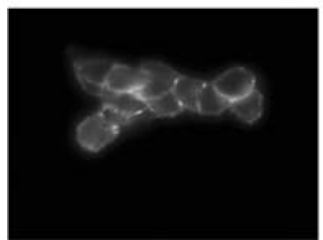

FITC

C.

DAOY

Untreated

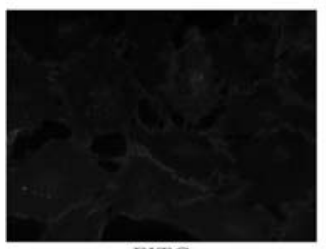

FITC

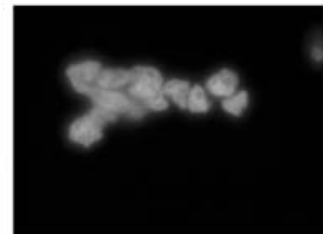

DAPI

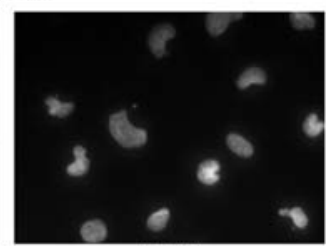

DAPI

B.

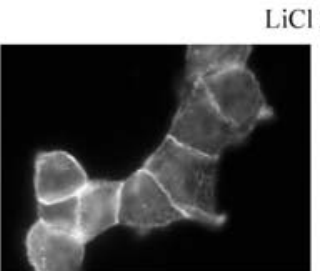

FITC

D283MED

$\mathrm{LiCl} 24 \mathrm{~h}$

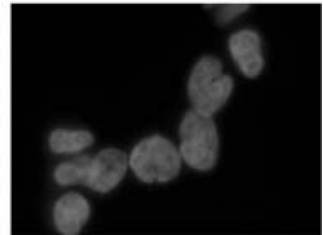

DAPI

D.

DAOY

$\mathrm{LiCl} 24 \mathrm{~h}$

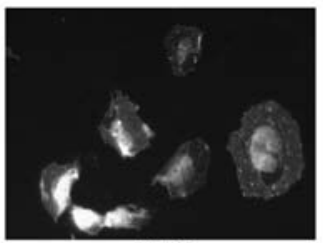

FITC

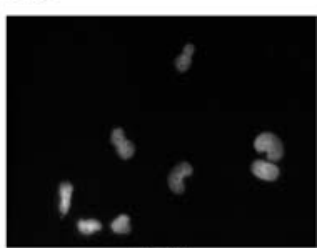

DAPI

Figure 3. Effect of $\mathrm{LiCl}$ on $\beta$-catenin localization in D283MED (A, B) and DAOY (C, D). Expression of ß-catenin was evaluated with FITC immunofluorescence on untreated cells (A, C) and on cells treated with $20 \mathrm{mM} \mathrm{LiCl}$ for $24 \mathrm{~h}$ (B, D). Nuclei were counterstained with DAPI. The experiment was replicated two times. Magnification, $\mathrm{x} 40$.

decreased slightly compared to previous time-points, in agreement with a cell synchronization in the $\mathrm{G} 2 / \mathrm{M}$ phase after escaping a block in the cell cycle (Fig. 5B). In both cell lines, statistically significant cell mortality increased in response to lithium treatment. In particular, in D283MED, the percentages between dead and total cells, respectively, at 

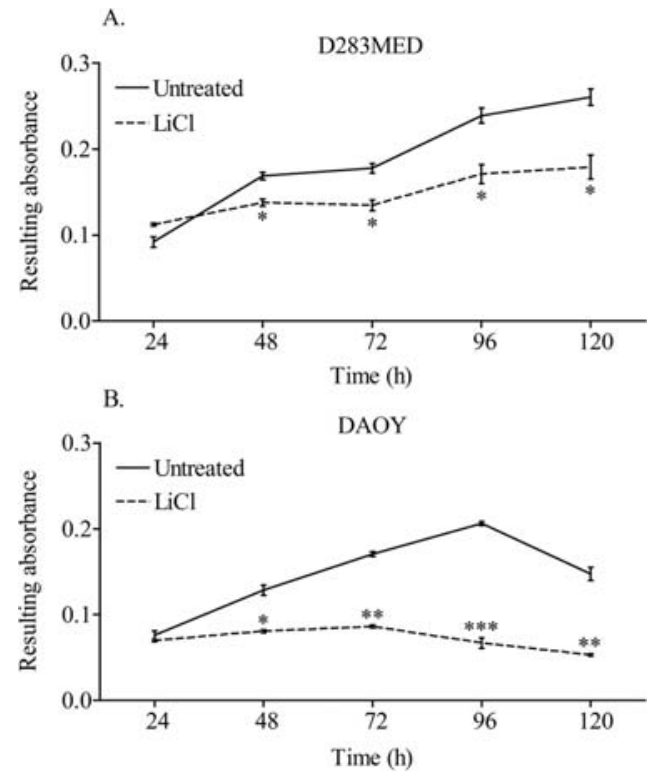

Figure 4. Effect of $\mathrm{LiCl}$ on cell proliferation in D283MED (A) and DAOY (B). The cells were analyzed 24, 48, 72, 96 and $120 \mathrm{~h}$ after $\mathrm{LiCl}$ addition $(20 \mathrm{mM})$ (dotted line) and untreated cells were harvested at the corresponding timepoints (continuous line). Resulting absorbance represents the difference between the formazan product absorbance at a wave-length of $550 \mathrm{~nm}$ and the reference absorbance at $660 \mathrm{~nm}$. Each data point ( \pm SEM; point) is the mean of three independent experiments. p-value ( $\mathrm{LiCl}$ vs. untreated) was: ${ }^{*} \mathrm{p}<0.05 ;{ }^{* *} \mathrm{p}<0.01 ;{ }^{* * *} \mathrm{p}<0.001$.

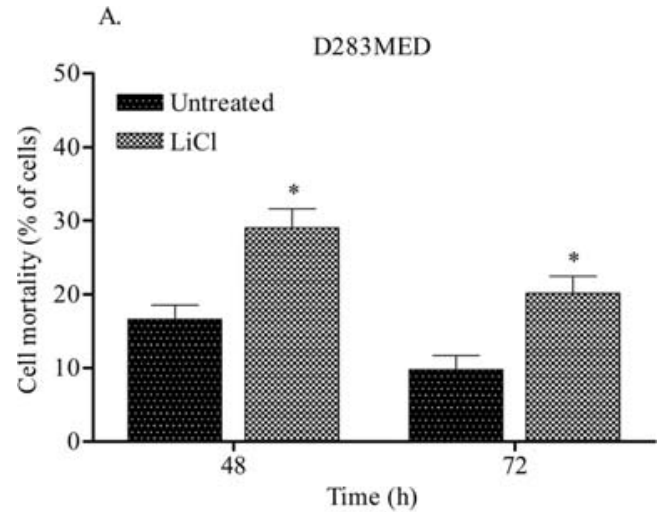

B.

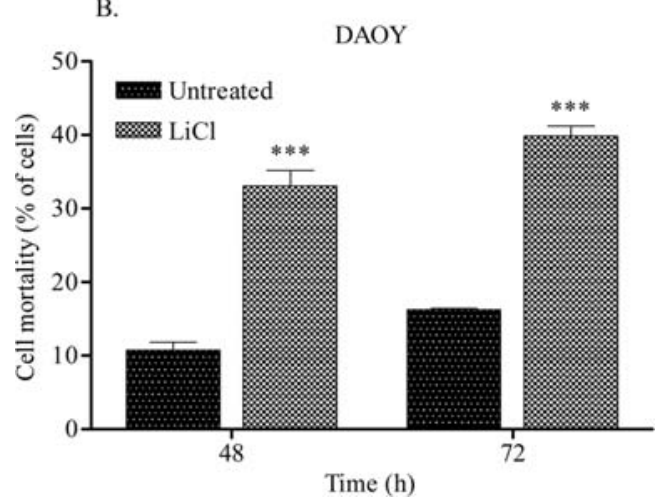

Figure 6. Effect of $\mathrm{LiCl}$ on cell mortality of D283MED (A) and DAOY (B). Cells were harvested in triplicate after 48 and $72 \mathrm{~h}$ of $20 \mathrm{mM} \mathrm{LiCl}$ treatment and untreated cells were collected at the corresponding time points. Graphs represent the percentages between dead and total cells and column bars ( \pm SEM; bar) show the means of two independent experiments. $p$-value (LiCl vs. untreated) was: ${ }^{*} \mathrm{p}<0.05 ;{ }^{*} \mathrm{p}<0.01 ;{ }^{* * *} \mathrm{p}<0.001$.
A.

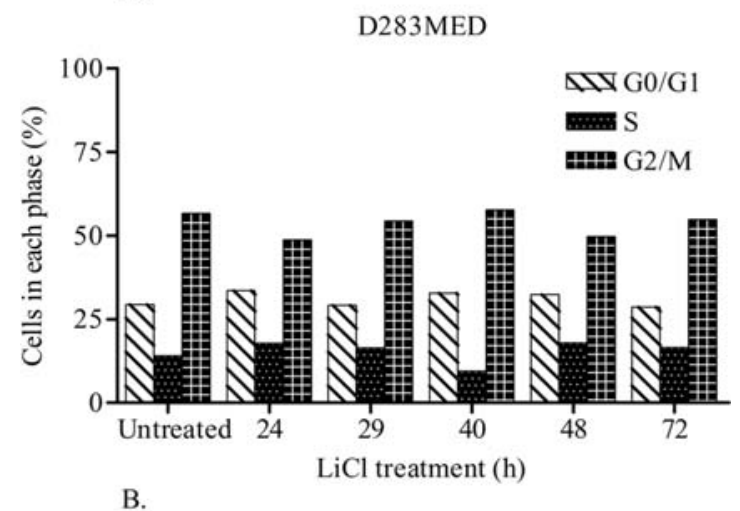

DAOY

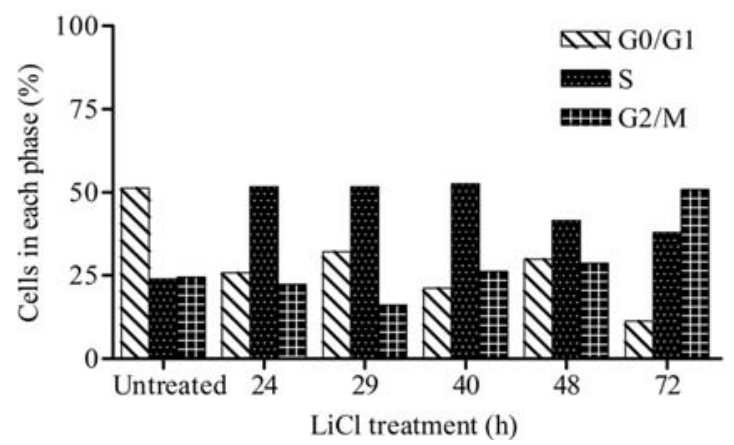

Figure 5. Effect of $\mathrm{LiCl}$ on cell cycle in D283MED (A) and DAOY (B). Samples of untreated cells and cells treated with $20 \mathrm{mM} \mathrm{LiCl}$ for $24,29,40$, 48 and $72 \mathrm{~h}$. Percentage of cells in each cycle phase was measured by flow cytometry. Bar charts show the means of two independent experiments.

48 and $72 \mathrm{~h}$ were $16.63,9.80$ for untreated controls and 29.05, 20.17\% for treated cells (Fig. 6A). In DAOY, the increase in mortality was greater than in D283MED and the percentages of dead cells were $10.73,16.24 \%$ for untreated cells and $33.05,39.80 \%$ for lithium treatment, at $48 \mathrm{~h}$ and $72 \mathrm{~h}$, respectively (Fig. 6B). Increase in cell death was not supported by an increase of apoptotic cells compared to untreated cells, both in D283MED and in DAOY. The amount of apoptotic cells was not statistically significantly different between treated and control samples (Fig. 7A and B).

D283MED die at lithium clinical dose. In D283MED, $20 \mathrm{mM}$ lithium induced a rapid and massive increase in mortality, in fact, after 10 days of treatment, almost all the cells were dead. From the 2 nd day of lithium treatment at $20 \mathrm{mM}$, the increase in mortality of treated cells was statistically significantly higher compared to untreated cells. As regards lithium at $10 \mathrm{mM}$ dose, the first statistically significant increase in mortality was observed from the 10th day of treatment onwards and after 35 days all cells were dead. After treatment with $1 \mathrm{mM}$ lithium, late mortality was induced and a statistically significant increase was observed only from the 42nd day of treatment; then cell mortality further increased. Even if total mortality was not achieved during the observation period, it is important to consider that after 45 days of $1 \mathrm{mM}$ lithium we obtained a mortality comparable to that obtained after 2 days of $20 \mathrm{mM}$ lithium (first time-point statistically significant for $20 \mathrm{mM}$ lithium). In decreasing the 


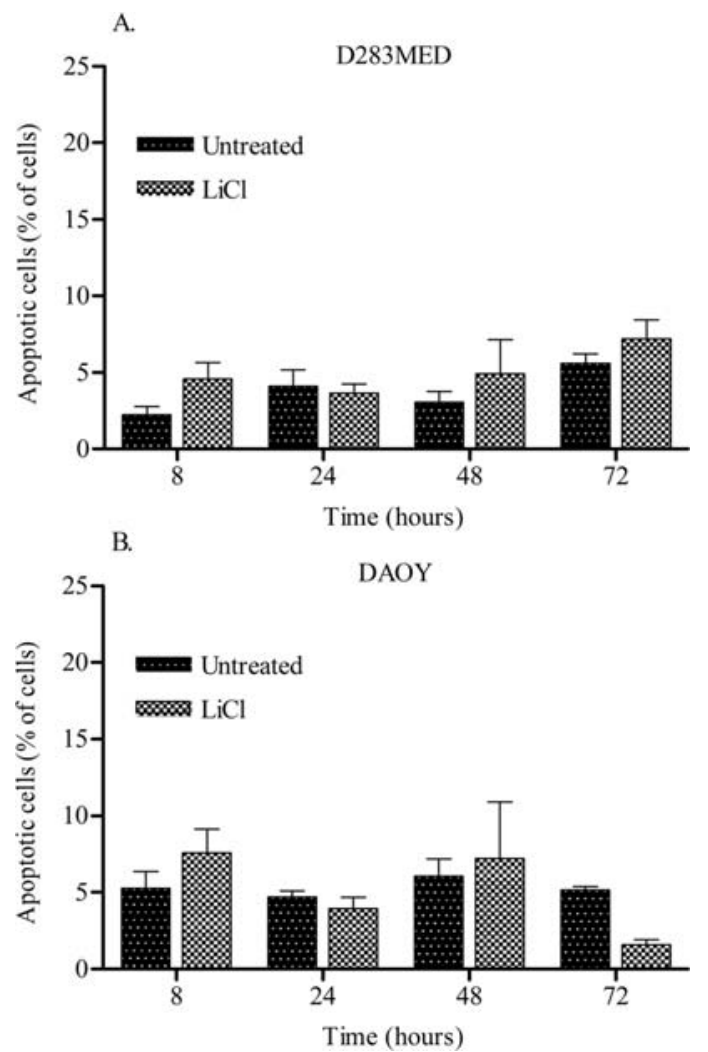

Figure 7. Effect of $\mathrm{LiCl}$ on apoptosis in D283MED (A) and DAOY (B) Cells were harvested at $8,24,48$ and $72 \mathrm{~h}$ of $\mathrm{LiCl}$ treatment and untreated cells at the corresponding time-points. Bar charts show the means of three independent experiments.

Table I. Cell mortality of D283MED in response to different doses of $\mathrm{LiCl}$ (mean percentages of dead on total cells).

\begin{tabular}{lccccc}
\hline $\begin{array}{l}\text { Time } \\
\text { (days) }\end{array}$ & $\begin{array}{c}\text { Untreated } \\
\%\end{array}$ & $\begin{array}{c}0.5 \mathrm{mM} \\
\%\end{array}$ & $\begin{array}{c}1 \mathrm{mM} \\
\%\end{array}$ & $\begin{array}{c}10 \mathrm{mM} \\
\%\end{array}$ & $\begin{array}{c}20 \mathrm{mM} \\
\%\end{array}$ \\
\hline 0 & 27.07 & 24.50 & 21.34 & 24.92 & 28.00 \\
1 & 25.45 & 29.12 & 23.75 & 28.24 & 34.60 \\
2 & 23.08 & 25.46 & 27.98 & 28.54 & $37.30^{\mathrm{a}}$ \\
3 & 24.56 & 24.92 & 21.92 & 30.15 & $52.85^{\mathrm{b}}$ \\
7 & 25.28 & 25.68 & 25.41 & 29.25 & $65.68^{\mathrm{c}}$ \\
10 & 23.73 & 21.22 & 22.26 & $43.35^{\mathrm{a}}$ & $95.40^{\mathrm{c}}$ \\
14 & 24.61 & 30.81 & 28.70 & $46.30^{\mathrm{a}}$ & - \\
17 & 23.43 & 25.35 & 27.57 & $59.40^{\mathrm{c}}$ & - \\
21 & 17.17 & 25.22 & 29.86 & $65.37^{\mathrm{c}}$ & - \\
24 & 14.27 & 19.84 & 24.40 & $58.25^{\mathrm{c}}$ & - \\
28 & 16.09 & 24.32 & 24.60 & $69.72^{\mathrm{c}}$ & - \\
31 & 12.89 & 15.15 & 20.05 & $79.37^{\mathrm{c}}$ & - \\
35 & 13.29 & 18.94 & 22.16 & $95.83^{\mathrm{c}}$ & - \\
38 & 9.77 & 12.81 & 17.76 & - & - \\
42 & 14.38 & 20.39 & $26.00^{\mathrm{a}}$ & - & - \\
45 & 11.42 & 11.86 & $37.27^{\mathrm{c}}$ & - & - \\
49 & 10.80 & 12.40 & $44.61^{\mathrm{c}}$ & - & - \\
\hline
\end{tabular}

p-value ( $\mathrm{LiCl}$ vs. untreated): ${ }^{\mathrm{a}} \mathrm{p}<0.05 ;{ }^{\mathrm{b}} \mathrm{p}<0.01 ;{ }^{\mathrm{c}} \mathrm{p}<0.001$.
A.

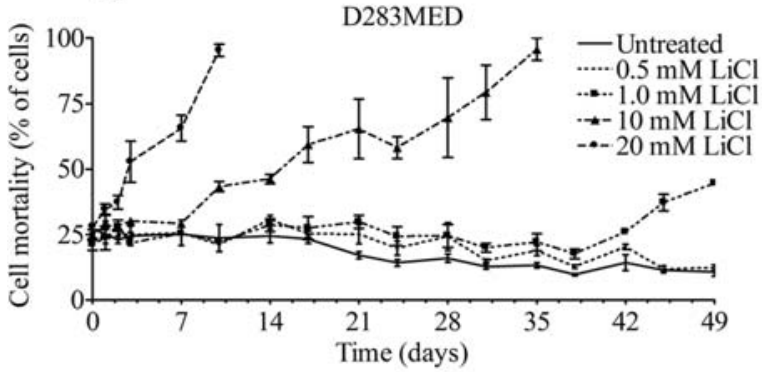

B.

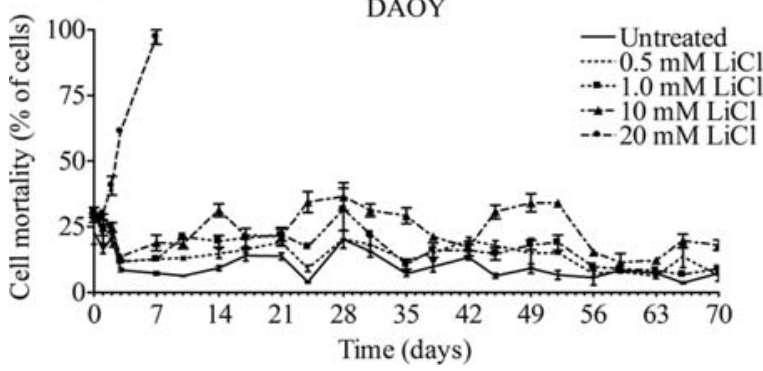

Figure 8. Cell mortality of D283MED (A) and DAOY (B) untreated and in response to $0.5,1,10$ and $20 \mathrm{mM}$ doses of $\mathrm{LiCl}$. Total D283MED and DAOY cells were collected in triplicate for 49 and 70 days, respectively. Graphs represent the percentages between dead and total cells and each data point ( \pm SEM; point) shows the means of two independent experiments.

dose of lithium to $0.5 \mathrm{mM}$, no statistically significant increases in cell mortality were observed (Fig. 8A, Table I). In DAOY, in response to $20 \mathrm{mM}$ lithium we observed a statistically significant induction of mortality from the 2nd day of treatment and after 7 days all of the cells were dead. After the addition of $10 \mathrm{mM}$ lithium, the effect on cell mortality was completely different. We observed statistically significant increases in mortality followed by trend reversals, so the general trend in the observation period is difficult to interpret and after 70 days of treatment the cell population was still mostly alive. Lithium treatment at the clinical doses of 1 and $0.5 \mathrm{mM}$ did not induce cell mortality in DAOY (Fig. 8B, Table II).

\section{Discussion}

In the literature, it has been reported that lithium, an inhibitor of GSK-3B, has anti-neoplastic effects in human melanoma, hepatocellular carcinoma, prostate cancer and glioma $(7,12-$ 14). It is well-known that lithium mimics the activation of the Wnt pathway, leading to nuclear accumulation of $\beta$-catenin, an independent marker of a good outcome in MB (24-26). For these reasons, we have analyzed the effects of lithium on two MB cell lines that, deriving from primary tumours of different histopathological variants, have a different molecular arrangement $(28,29)$. In particular, these cell lines are different for the status of p53: one has p53 wild-type and the other harbours mutated p53 (29). In both cell lines, the inhibition of GSK-3ß activity after $\mathrm{LiCl}$ treatment was confirmed by the increase of phosphorylated (inactive) GSK-3B in treated cells compared to untreated. The main action of GSK-3ß is to induce the degradation of $\beta$-catenin and, therefore, GSK-3ß inhibition leads to $\beta$-catenin stabilization 
Table II. Cell mortality of DAOY in response to different doses of $\mathrm{LiCl}$ (mean percentages of dead on total cells).

\begin{tabular}{|c|c|c|c|c|c|}
\hline $\begin{array}{l}\text { Time } \\
\text { (days) }\end{array}$ & $\begin{array}{c}\text { Untreated } \\
\%\end{array}$ & $\begin{array}{c}0.5 \mathrm{mM} \\
\%\end{array}$ & $\begin{array}{c}1 \mathrm{mM} \\
\%\end{array}$ & $\begin{array}{c}10 \mathrm{mM} \\
\%\end{array}$ & $\begin{array}{c}20 \mathrm{mM} \\
\%\end{array}$ \\
\hline 0 & 23.00 & 30.43 & 30.49 & 30.09 & 28.33 \\
\hline 1 & 16.31 & 21.91 & $27.89^{\mathrm{a}}$ & 24.69 & 30.00 \\
\hline 2 & 20.89 & 21.37 & 25.32 & 24.73 & $40.65^{\mathrm{c}}$ \\
\hline 3 & 8.58 & 11.71 & 11.85 & 13.60 & $61.27^{\mathrm{c}}$ \\
\hline 7 & 7.30 & 12.71 & 12.57 & $18.85^{\mathrm{a}}$ & $97.25^{\mathrm{c}}$ \\
\hline 10 & 6.33 & 13.04 & 21.11 & 18.52 & - \\
\hline 14 & 9.31 & 14.74 & 19.50 & $31.28^{\mathrm{a}}$ & - \\
\hline 17 & 14.10 & 16.36 & 20.74 & 21.80 & - \\
\hline 21 & 13.78 & 19.09 & 21.89 & 21.22 & - \\
\hline 24 & 3.98 & 9.20 & 17.31 & $34.39^{\mathrm{b}}$ & - \\
\hline 28 & 20.16 & 20.28 & 31.60 & 36.47 & - \\
\hline 31 & 15.67 & 18.32 & 22.16 & 31.33 & - \\
\hline 35 & 7.19 & 12.17 & 10.71 & $29.21^{\mathrm{a}}$ & - \\
\hline 38 & 9.93 & 14.87 & 16.05 & 21.30 & - \\
\hline 42 & 13.28 & 19.90 & 16.00 & 17.02 & - \\
\hline 45 & 6.35 & 17.83 & 14.70 & $30.66^{\mathrm{b}}$ & - \\
\hline 49 & 9.15 & 14.98 & 18.07 & $34.15^{\mathrm{b}}$ & - \\
\hline 52 & 6.66 & 15.03 & 18.99 & $33.95^{\mathrm{b}}$ & - \\
\hline 56 & 5.71 & 7.16 & 9.77 & 15.32 & - \\
\hline 59 & 8.54 & 8.04 & 8.94 & 11.40 & - \\
\hline 63 & 7.32 & 6.19 & 8.35 & 12.27 & - \\
\hline 66 & 3.68 & 13.68 & 6.82 & 19.61 & - \\
\hline 70 & 7.30 & 6.38 & 9.09 & 17.99 & - \\
\hline
\end{tabular}

p-value (LiCl vs. untreated): ${ }^{\mathrm{a}} \mathrm{p}<0.05 ;{ }^{\mathrm{b}} \mathrm{p}<0.01 ;{ }^{\mathrm{c}} \mathrm{p}<0.001$.

and translocation to the nucleus. Our WB data showed that, after $\mathrm{LiCl}$ treatment, levels of nuclear $\beta$-catenin increased in both cell lines. Although these data confirmed the action of lithium downstream of GSK-3ß, it should be noted that D283MED had constantly higher levels of nuclear B-catenin than the control, while DAOY had an increase in nuclear B-catenin after $24 \mathrm{~h}$ of treatment and then levels decreased until they were lower than the control ones. IF assay was performed to verify the increase in nuclear $\beta$-catenin levels after $\mathrm{LiCl}$ treatment, as observed by WB. However, D283MED are small cells with a high nucleus/cytoplasm ratio and they usually form cellular aggregates, therefore an exact subcellular localization is difficult to evaluate. We observed a widespread internal staining after the treatment, but we did not notice a clear nuclear accumulation. It is possible that this phenomenon could be observed later in time, when WB data showed a stronger increase in nuclear $\beta$-catenin. On the other hand, in DAOY, IF analysis showed an evident nuclear B-catenin localization $24 \mathrm{~h}$ after $\mathrm{LiCl}$ addition. In all cases, an effect of $\beta$-catenin stabilization due to GSK-3ß inhibition was revealed by both assays and data are in agreement. Although we have shown the effectiveness of the drug, in terms of GSK-3ß inhibition and the consequent increase in $\beta$-catenin, the reason why $\beta$-catenin levels decreased to control levels or less in DAOY is still unclear. It probably depends on the characteristic molecular background of this line, that seems to be able to compensate GSK-3B inhibition, as regards $\beta$-catenin stabilization. However, we can not exclude that other molecular effects triggered by the inhibition of a key enzyme, like GSK-3ß, are stimulated and maintained by exposure to lithium.

Although the molecular mechanisms involved in the response to lithium were found to be less linear than expected in our cell lines, we considered it important to assess whether GSK-3ß inhibition had an anti-neoplastic effect. In response to $\mathrm{LiCl}$ treatment, both cell lines showed alterations in cell proliferation, cell cycle and mortality. In particular, D283MED suffered a slowdown in proliferation, a transient decrease of the number of cells in the S-phase and an increase in mortality. At $48 \mathrm{~h}$ from the treatment, the cell cycle was re-established but the resumption of the cycle was not sufficient to compensate cell mortality. DAOY proliferation was inhibited by metabolic arrest until at least $120 \mathrm{~h}$ of treatment and by a great increase in mortality. Observed increase in cells in the S-phase did not overlap with the proliferation, therefore it was interpreted as a block in S-phase and not an increase in proliferating cells; moreover, several studies report that lithium can have this effect (7). The block was persistent until $48 \mathrm{~h}$ of treatment and then the number of cells blocked decreased, resulting in a cell synchronization in $\mathrm{G} 2 / \mathrm{M}$ phase. Simultaneously, increased mortality suggested that the cells that escaped the block then died. Cytofluorimetric analysis suggested that lithium triggered a non-apoptotic cell death both in D283MED and in DAOY. We have to underline that apoptosis, very important and beneficial to the whole body, is one of several types of cell death, among which there are necrosis, mitotic catastrophe and autophagocytosis $(30,31)$. All these data are in agreement and explain how lithium induced a decrease in the number of metabolically active cells. Finally, in DAOY we observed a higher induction of mortality compared to D283MED and a cell cycle arrest, explaining the more marked and progressive decrease in proliferation. Even with these small differences, biological response to lithium was comparable in both cell lines but, as previously explained, nuclear B-catenin levels had different trends. Therefore, we concluded that the observed effects were completely independent of Wnt-pathway activation; we cannot definitevely exclude that $\beta$-catenin translocation to the nucleus, even if transient in DAOY, triggered molecular responses similar to those in D283MED, where high nuclear levels were persistent, inducing the same cellular effect. Although it is not possible to clarify the underlying molecular mechanism with these data, we observed significant biological effects in response to $20 \mathrm{mM}$ lithium. The inhibition of proliferation and the induction of cell death are among the expected effects of an anti-neoplastic drug. Therefore, we assessed cell mortality even at doses lower than $20 \mathrm{mM}$, including the clinical doses of 1 and $0.5 \mathrm{mM}$. The clinical dose of $1 \mathrm{mM}$ lithium had the desired effect of inducing mortality in D283MED, but not in DAOY, indicating that lithium could be a promising molecule from a therapeutic point of view, depending on the molecular background.

In conclusion, lithium exerts anti-neoplastic effects at the high dose of $20 \mathrm{mM}$ in both in vitro models of MB. From our 
data, lithium effects can be assigned to GSK-3ß inhibition $(32,33)$, rather than to a specific Wnt activation, even if this molecular pathway is altered by the drug in both cell lines. On the other hand, the clinical dose of $1 \mathrm{mM}$ lithium elicits anti-neoplastic effects only in D283MED cells. Therefore, lithium could be a promising drug in $\mathrm{MB}$, but only in some subtypes of MB with a specific molecular background. Moreover, $\mathrm{MB}$ is an extremely heterogeneous tumour, from both a histopathological and a molecular point of view, so it is not probable that a targeted therapy could be effective in all patients. Specific molecular markers predictive of the response of this drug still need to be clarified.

\section{Acknowledgements}

This research project was supported by PRIN 2006 and MIUR ex $60 \%$ grants.

\section{References}

1. Severus WE, Kleindestein N, Seemuler F, Frangou S, Moller HJ and Greil W: What is the optimal serum lithium level in the long-term treatment of bipolar disorder - a review? Bipolar Disord 10: 231-237, 2008.

2. Phiel CJ and Klein PS: Molecular targets of lithium action. Annu Rev Pharmacol Toxicol 41: 789-813, 2001.

3. Williams R, Ryves WJ, Dalton EC, Eickholt B, Shaltiel G, Agam $\mathrm{G}$ and Harwood AJ: A molecular cell biology of lithium. Biochem Soc Trans 32: 799-802, 2004.

4. Smits VA, Essers MA, Loomans DS, Klompmaker R, Rijksen G and Medema RH: Inhibition of cell proliferation by lithium is associated with interference in cdc2 activation. FEBS Lett 457 23-27, 1999.

5. Mao CD, Hoang P and DiCorleto PE: Lithium inhibits cell cycle progression and induces stabilization of p53 in bovine aortic endothelial cells. J Biol Chem 276: 26180-26188, 2001.

6. Karlovic D, Jakopec S, Dubravcic K, Batinic D, Buljan D and Osmak M: Lithium increases expression of p21(WAF/Cip1) and survivin in human glioblastoma cells. Cell Biol Toxicol 23: 83-90, 2007.

7. Sun A, Shanmugam I, Song J, Terranova PF, Thrasher JB and Li B: Lithium suppresses cell proliferation by interrupting E2FDNA interaction and subsequently reducing S-phase gene expression in prostate cancer. Prostate 67: 976-988, 2007.

8. Song L, Zhou T and Jope RS: Lithium facilitates apoptotic signaling induced by activation of the Fas death domaincontaining receptor. BMC Neurosci 5: 20, 2004.

9. Sarkar S, Floto RA, Berger Z, Imarisio S, Cordenier A, Pasco M, Cook LJ and Rubinsztein DC: Lithium induces autophagy by inhibiting inositol monophosphatase. J Cell Biol 170: 1101-1111, 2005.

10. Zhang WV, Jüllig M, Connolly AR and Stott NS: Early gene response in lithium chloride induced apoptosis. Apoptosis 10: 75-90, 2005

11. Welshons WV, Engler KS, Taylor JA, Grady LH and Curran EM: Lithium-stimulated proliferation and alteration of phosphoinositide metabolites in MCF-7 human breast cancer cells. J Cell Physiol 165: 134-144, 1995.

12. Penso $J$ and Beitner R: Lithium detaches hexokinase from mitochondria and inhibits proliferation of B16 melanoma cells. Mol Genet Metab 78: 74-78, 2003.

13. Erdal E, Ozturk N, Cagatay T, Eksioglu-Demiralp E and Ozturk M: Lithium-mediated downregulation of PKB/Akt and cyclin E with growth inhibition in hepatocellular carcinoma cells. Int J Cancer 115: 903-910, 2005.

14. Nowicki MO, Dmitrieva N, Stein AM, Cutter JL, Godlewski J, Saeki Y, Nita M, Berens ME, Sander LM, Newton HB, Chiocca EA and Lawler S: Lithium inhibits invasion of glioma cells; possible involvement of glycogen synthase kinase-3. Neuro Oncol 10: 690-699, 2008.
15. D'Mello SR, Anelli R and Calissano P: Lithium induces apoptosis in immature cerebellar granule cells but promotes survival of mature neurons. Exp Cell Res 211: 332-338, 1994.

16. Hongisto V, Smeds N, Brecht S, Herdegen T, Courtney MJ and Coffey ET: Lithium blocks the c-Jun stress response and protects neurons via its action on glycogen synthase kinase 3 . Mol Cell Biol 23: 6027-6036, 2003.

17. Chen RW and Chuang DM: Long term lithium treatment suppresses p53 and Bax expression but increases Bcl-2 expression. A prominent role in neuroprotection against excitotoxicity. J Biol Chem 274: 6039-6042, 1999.

18. Manji HK, Moore GJ and Chen G: Lithium upregulates the cytoprotective protein Bcl-2 in vitro and in the CNS in vivo: a role of neurotrophic and neuroprotective effects in maniacdepressive illness. J Clin Psychiatry 61: 82-96, 2000.

19. Kang HJ, Noh JS, Bae YS and Gwag BJ: Calcium-dependent prevention of neuronal apoptosis by lithium ion: essential role of phosphoinositide 3-kinase and phospholipase Cgamma. Mol Pharmacol 64: 228-234, 2003

20. Klein PS and Melton DA: A molecular mechanism for the effect of lithium on development. Proc Natl Acad Sci USA 93: 8455-8459, 1996.

21. Cohen P and Goedert M: GSK-3 inhibitors: development and therapeutic potential. Nat Rev Drug Discov 3: 479-487, 2004

22. Jope RS and Johnson GV: The glamour and gloom of glycogen synthase kinase-3. Trends Biochem Sci 29: 95-102, 2004.

23. Kim L and Kimmel AR: GSK-3, a master switch regulating cell-fate specification and tumorigenesis. Curr Opin Genet Dev 10: 508-514, 2000.

24. Stambolic V, Ruel L and Woodgett JR: Lithium inhibits glycogen synthase kinase-3 activity and mimics Wingless signalling in intact cells. Curr Biol 6: 1664-1668, 1996.

25. Ellison DW, Onilude OE, Lindsey JC, Lusher ME, Weston CL, Taylor RE, Pearson AD and Clifford SC: Beta-catenin status predicts a favorable outcome in childhood medulloblastoma: the United Kingdom Children's Cancer Study Group Brain Tumor Committee. J Clin Oncol 23: 7951-7957, 2005.

26. Clifford SC, Lusher ME, Lindsey JC, Langdon JA, Gilbertson RJ, Straughton D and Ellison DW: Wnt/Wingless pathway activation and chromosome 6 loss characterize a distinct molecular sub-group of medulloblastomas associated with a favorable prognosis. Cell Cycle 5: 2666-2670, 2006.

27. Fattet S, Haberler C, Legoix P, Varlet P, Lellouch-Tubiana A, Lair S, Manie E, Raquin MA, Bours D, Carpentier S, Barillot E, Grill J, Doz F, Puget S, Janoueix-Lerosey I and Delattre O: Beta-catenin status in paediatric medulloblastomas: correlation of immunohistochemical expression with mutational status, genetic profiles, and clinical characteristics. J Pathol 218: 86-94, 2009.

28. Salaroli R, Russo A, Ceccarelli C, Mina GD, Arcella A, Martinelli GN, Giangaspero F, Capranico G and Cenacchi G: Intracellular distribution of beta-catenin in human medulloblastoma cell lines with different degree of neuronal differentiation. Ultrastruct Pathol 31: 33-44, 2007.

29. Salaroli R, Di Tomaso T, Ronchi A, Ceccarelli C, Cammelli S, Cappellini A, Martinelli GN, Barbieri E, Giangaspero F and Cenacchi G: Radiobiologic response of medulloblastoma cell lines: involvement of beta-catenin? J Neurooncol 90: 243-251, 2008.

30. Belka C: The fate of irradiated tumor cells. Oncogene 25: 969-971, 2006.

31. Tasdemir E, Chiara Maiuri M, Morselli E, Criollo A, D'Amelio M, Djavaheri-Mergny M, Cecconi F, Tavernarakis N and Kroemer G: A dual role of p53 in the control of autophagy. Autophagy 4: 810-814, 2008.

32. Bilim V, Ougolkov A, Yuuki K, Naito S, Kawazoe H, Muto A, Oya M, Billadeau D, Motoyama T and Tomita Y: Glycogen synthase kinase-3: a new therapeutic target in renal cell carcinoma. Br J Cancer 101: 2005-2014, 2009.

33. Mamaghani S, Patel S and Hedley DW: Glycogen synthase kinase-3 inhibition disrupts nuclear factor-kappaB activity in pancreatic cancer, but fails to sensitize to gemcitabine chemotherapy. BMC Cancer 9: 132, 2009. 